\title{
Bacterial Diseases of Wheat Caused by Xanthomonas sp. in the Southern Ural: Identification Issues
}

\author{
A. P. GLINUSHKIN ${ }^{*}$, O. O. BELOSHAPKINA ${ }^{2}$, A. A. SOLOVYKH ${ }^{3}$, \\ V. S. LUKYANTSEV ${ }^{3}$, A. A. BATMANOVA ${ }^{1}$, G. V. SUDARENKOV ${ }^{1}$ \\ and J. MOLNÁR ${ }^{1}$
${ }^{1}$ All-Russian Research Institute of Phytopathology of Federal Agency of Scientific Organizations of Russia, Leninsky Prospekt 32a, Moscow, Russia
${ }^{2}$ Russian State Agrarian University, Moscow Timiryazev Agricultural Academy, Timiryazevskaya st. 49, Moscow, Russia
${ }^{3}$ Orenburg State Agrarian University, Chelyuskintsev st. 18, Orenburg, Russia

(Received: 16 June 2015; accepted: 27 January 2016)

\begin{abstract}
The identification of pathogenic agents isolated from infected wheat seeds and plants, collected in the Southern Ural and characterized by an atypical manifestation of bacterial infection (yellow leaf tips), has been carried out by direct microbiological and molecular methods. In addition, an indirect identification by the hypersensitive reaction (HR) approach has been performed simultaneously with the pathogenicity assessment of isolates using an indicator plant Plectranthus australis R. Br. Isolated samples have been microbiologically identified as Xanthomonas sp. According to the results of the PCR identification with species-specific primers, isolated samples represent Xanthomonas translucens; the reliability of the obtained results is corroborated by the hypersensitive reaction approach used also to assess the pathogenicity of isolates. Winter wheat, especially cv. Pionerskaya 23, where both X. translucens and Pantoea agglomerans were found, suffered more severe symptoms than spring wheat that was only affected by strains of $X$. translucens. To improve the reliability of the primary diagnostics of a bacterial character of seed infection, the provoking of the pathogen development by temperature or $\mathrm{pH}$ stress is proposed.
\end{abstract}

Keywords: wheat, bacterial diseases, Xanthomonas translucens, Pantoea agglomerans, pathogenicity, hypersensitive reaction, diagnostics.

In recent years, an increase in the crop infection with both fungal and bacterial diseases is observed in Russia as well as in other countries (Ignatov, 2014). This phenomenon is based on the changes of climatic conditions, failures in the technologies of cultivation, harvesting and storage of seeds, and the lack of timely and accurate plant pathogen diagnostics. A great variety of phytopathogenic bacterial strains and isolates makes their identification difficult for researchers.

In spite of a significant harm by bacterial diseases, the majority of farmers are unaware of the real origin of the reduced plant productivity, since the symptoms of bacterial infection are similar to those of other infectious diseases or abiotic stress factors. Never-

* Corresponding author; e-mail: glinale@gmail.com 
theless, visual diagnosis still remains to be the primary action in the course of monitoring surveys, because it provides a quite accurate diagnostics of a bacterial infection based on revealed symptoms, especially when they are of a specific nature. According to our earlier studies, bacterial diseases of wheat in the steppe zone of the Southern Ural are caused mainly by bacteria from the genus Xanthomonas (Glinushkin, 2013).

Sometimes it is impossible to say that plants or soil are infected by plant pathogenic bacteria based only on the manifestation of infection on plants or on the appearance of bacterial colonies cultivated on artificial medium (Kharchenko, 2012). For example, the study of winter wheat samples, collected in the Moscow, Ryazan and Lipetsk regions, performed at the All-Russian Research Institute of Phytopathology, showed that, despite the presence of the corresponding symptoms, only $25 \%$ of analyzed samples were really infected with phytopathogenic bacteria (Ignatov et al., 2012; Egorova et al., 2014). According to the above-mentioned authors, in addition to pathogenic Pseudomonas syringae and $P$. marginalis, which infect many cultivated and wild plants, some nonpathogenic Pseudomonas, such as P. fluorescens, are also present in soil and on plant roots, stems and leaves and often antagonize phytopathogens. The indirect evaluation of bacterial infection by the level of deterioration of physical properties of flour or by a visual evaluation of a slimy seed fraction during germination also does not able to provide the exact and correct picture, and, therefore, are also unsuitable for correct diagnosis.

Initially, plant pathogenic bacteria were identified by microscopy or microbiological methods with the confirmation of their pathogenicity by Koch's postulates. Since the beginning of the 21st century the methods used to identify these bacteria have significantly changed, and the diagnostics of pathogenic objects and their infectious cycles became more precise and sensitive (Schaad et al., 2003). New highly-sensitive methods, such as the serologic identification with species-specific bacterial proteins (ELISA and immunofluorescence assay) and PCR, became common. The pathogenicity of isolates is now evaluated by testing their ability to evoke an HR on indicator plants. In recent years, DNA sequencing of bacteria is also used for identification purposes.

During earlier field surveys we noted that the harmfulness and level of development of bacterial diseases increased under extreme environmental conditions. Therefore, we supposed that the reliability of the primary diagnostics of bacterial infection can be improved via the artificial modeling of stress situations providing stronger infection of plants with bacteria as facultative parasites. As a rule, such stress situations are provided by the use of heavy metal salts or by salinization (Prasada, et al., 2005). However, in many small regional institutions and organizations, researchers do not have reagents required for such experiments. Therefore, the need in more simple methods exists.

The purpose of this study was the identification of pathogens causing bacterial diseases of wheat in crops and seed material in Southern Ural and the optimization of their diagnostics via the use of temperature and $\mathrm{pH}$ as possible stress factors enhancing disease manifestations. 


\section{Materials and Methods}

\section{Sample collection}

In the course of the study, the crops of spring and winter wheat located in the steppe zone of the Southern Ural were examined. The field survey and sample collection was performed in 2011-2012. The total number of samples was 194. The level of seed infection was assessed for the following wheat cultivars:

- winter wheat: Orenburgskaya 105, Povolzhskaya 86, Pionerskaya 32, Kolos Orenburzhya;

- spring wheat: Saratovskaya 42, Albidum 188, Uchitel, Orenburgskaya 10, Orenburgskaya 21, Varyag.

The initial detection of bacterial infections was performed by several methods including the visual assessment, manifestation of infection in a moist chamber, seed germination in filter paper rolls with the further counting of infected seeds, and agro-ecological monitoring. Then the infected material was studied by common microscopic and microbiological methods used in plant pathology.

\section{Isolation of bacteria}

Seeds or fragments of plants with obvious signs of infection on leaf tips (Fig. 1) were placed into gauze pouches and soaked in $0.5 \%$ potassium permanganate for 3-5 min. Then pouches were placed into tap water for $5 \mathrm{~min}$, then placed for $3 \mathrm{~min}$ between filter paper sheets to remove the excess of water; this procedure was repeated three times, but the duration of the second and third soaking in water was 1-2 min. Finally, surface-sterilized samples were taken out of pouches, placed on starvation agar (1\% agar without any supplements), and then single bacterial colonies were obtained from the resulted bacterial mass by serial dilution method using standard semi-selective peptone-sucrose agar (PSA) and yeast-dextrose-calcium carbonate agar (YDS) media (Hayard, 1960; Vidaver, 1989).

\section{Morphological and microbiological identification}

The morphological, cultural, and pathogenic properties of obtained colonies suspected of being Xanthomonas were studied comparing to well-known reference Xanthomonas translucens pv. undulosa strain 926 from the State Collection of Phytopathogenic Microorganisms (All-Russian Research Institute of Phytopathology). Gram staining was done as described by Schaad et al. (2001). The morpho- and cytometry, as well as the determination of cell sizes and capsule formation of bacteria were carried out by the morphometric analysis of smears of 2-9-day-old gram-stained cultures and also by microscopic examination of bacteria, directly isolated from infected seeds and plants, using a Micros MSD 500 microscope (Austria) equipped with a digital camera, eyepiece-micrometer MOU-1-15x1500 (Russia) and a Test Morpho 4.0 software. Bacterial motility was visually determined under the microscope. The titer of bacteria was determined by serial dilution followed by inoculation on the PSA medium with the further counting of grown colonies. 


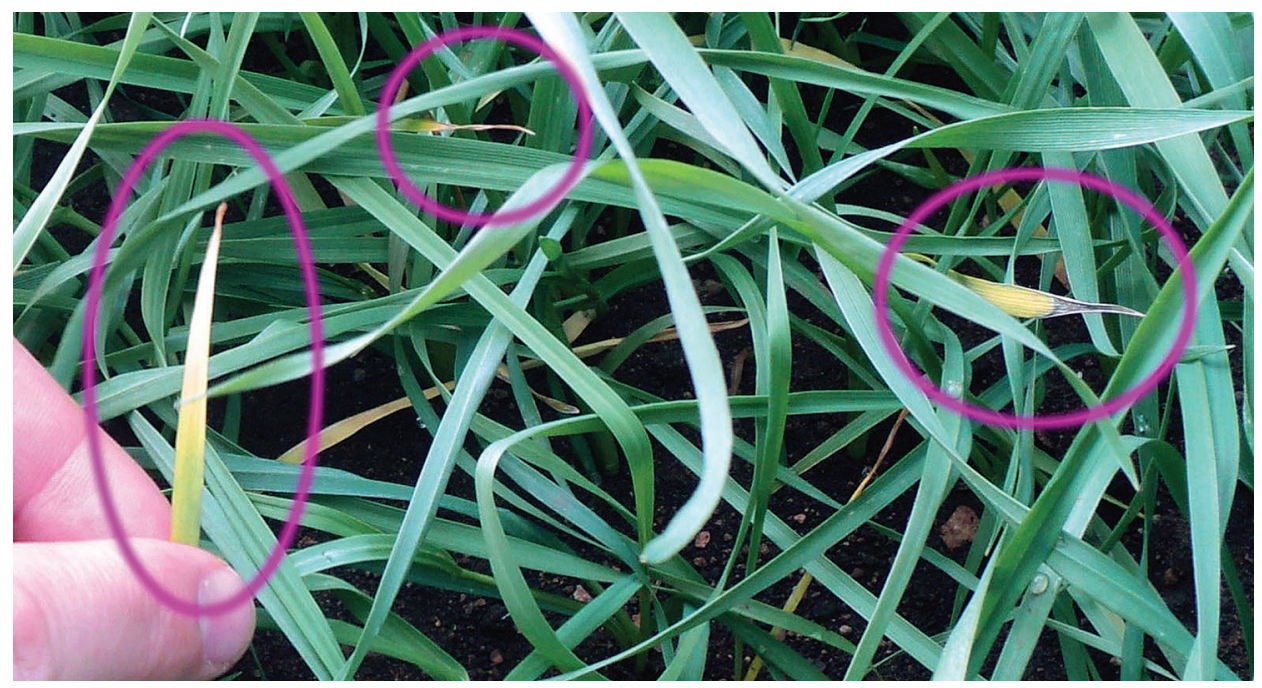

Fig. 1. Manifestation of bacterial infection on wheat seedlings (yellow leaf tips)

\section{Molecular identification}

The molecular identification of the pathogens from infected plant material was carried out by a PCR approach. Bacterial DNA was isolated using a modified alkaline method (Birnboim and Doly, 1979). The species-specific primers F25 (CCTACAGGCGTCCTCACAAGTAA) and R25 (TGATCTCAAACGCTCGCTACGTC) used in this study were specially designed at the Center of Bioengineering of the Russian Academy of Sciences (Punina et al., 2008). The PCR reaction mixture (15 $\mu \mathrm{l})$ was composed of $0.375 \mathrm{U}$ Taq polymerase (Fermentas), 1x Taq polymerase buffer, $0.3 \mathrm{mM}$ dNTP mix, $3.3 \mathrm{mM} \mathrm{MgCl}$, $0.7 \mathrm{pM}$ of forward primer, $0.7 \mathrm{pM}$ of reverse primer, and $0.5-1 \mu \mathrm{l}$ of template DNA. PCR was performed using a Mastercycler personal thermal cycler (Eppendorf, Germany) including negative and positive control reactions. The amplification reaction was performed as follows: primary initial activation step at $95{ }^{\circ} \mathrm{C}$ for $2 \mathrm{~min}$, followed by 35 cycles of 92 ${ }^{\circ} \mathrm{C}$ for $20 \mathrm{sec}, 67^{\circ} \mathrm{C}$ for $40 \mathrm{sec}$, and $72{ }^{\circ} \mathrm{C}$ for $45 \mathrm{sec}$, followed by final extension of $72{ }^{\circ} \mathrm{C}$ for $5 \mathrm{~min}$. The generated amplicons were visualized on $1.5 \%$ agarose gel electrophoresis stained with ethidium bromide and illuminated with a UV transilluminator.

\section{Indirect identification and pathogenicity evaluation by hypersensitive reaction (HR)} approach

An additional indirect identification of bacteria isolated from infected seed and plant samples was carried out for a subset of 32 samples using an indicator plant Plectranthus australis $\mathrm{R}$. Br. offered by researchers of the Center of Bioengineering of the Russian Academy of Sciences (see Results and Discussion section for more detailed information).

Leaves of $P$. australis were inoculated with bacterial cells at approximately $2 \times 10^{8} \mathrm{CFU} / \mathrm{ml}$ in a $0.85 \% \mathrm{NaCl}$ solution. The pathogen was introduced into the leaf 
apoplast by infiltration through the lower epidermis using a syringe with no needle fitted. Plant responses were observed 12 to $24 \mathrm{~h}$ after inoculation. The pathogenicity was assessed according to the development of necroses; the severity of infection was assessed by the size of resulting necroses and their development rate.

\section{Evaluation of the temperature effect on the germination rate and manifestation} of bacterial seed infection

Four replicates of 50 wheat seeds (cv. Albidum 188) were tested for their germination rate according to the International Seed Testing Association rules (ISTA, 1966). Germination in paper rolls was assessed after 7-day incubation at different temperatures within the range of $5-40{ }^{\circ} \mathrm{C}$. The standard temperature $\left(25^{\circ} \mathrm{C}\right)$ was used as the control. The level of bacterial infection was evaluated at the end of the incubation period by the fraction of seeds with obvious manifestations of bacterial infection.

\section{Evaluation of the $\mathrm{pH}$ effect on the germination rate and manifestation of bacterial seed infection}

Four replicates of 50 wheat seeds (cv. Uchitel) were tested for their germination rate according to the International Seed Testing Association rules (ISTA, 1966). Germination in paper rolls was assessed after 7-day incubation at different $\mathrm{pH}$ within the range of 7-10. To provide the required $\mathrm{pH}$ values, paper rolls with seeds were moistened with distilled water (control) or distilled water mixed with $0.1 \mathrm{M} \mathrm{KOH}$ solution in different ratios. The $\mathrm{pH}$ values were determined by a $\mathrm{pH}$ meter. The level of bacterial infection was evaluated at the end of the incubation period by the fraction of seeds with obvious manifestations of bacterial infection.

\section{Results and Discussion}

\section{Morphological and microbiological identification}

The identification of the genus of bacteria isolated from typical infected seeds and plants was carried out using microbiological methods in accordance with the Koch's postulates. We could not reliably determine the species composition of pathogens; however, according to the modern approach to the classification of microorganisms, due to a high variability of microorganisms, including their pathogenic characteristics, the identification of the genus of a pathogen is sufficient (Vauterin et al., 1995).

Since the identification of the causal agents of a bacterial infection, manifested as light-yellow necroses at the tips of leaves and causing the maximum damage to wheat in the region, was the most difficult, the results of its diagnostics are described in details below.

The bacteria from the genus Xanthomonas, presumably X. translucens were isolated from the infected samples of spring and winter wheat. These bacteria dominated 
not only in surveyed crops, but also during their isolation and cultivation on artificial media; they dominated not only in their number, but also in the growth and development rate of their colonies. The isolated bacteria were Gram-negative, aerobic, monotrichous, rod-shaped with rounded ends, and sporeless (but formed capsules). The size of observed bacteria varied with the prevalence of $0.1 \times 2.0 \mu \mathrm{m}$ (Fig. 2). Some long structures with the size of $0.05 \times 0.5 \mu \mathrm{m}$ and width-to-length ratio of 1:50 were observed. However, it was not clear either these structures represented chains of nonseparated cells, or were unusually long cells, so this question requires some additional studies.
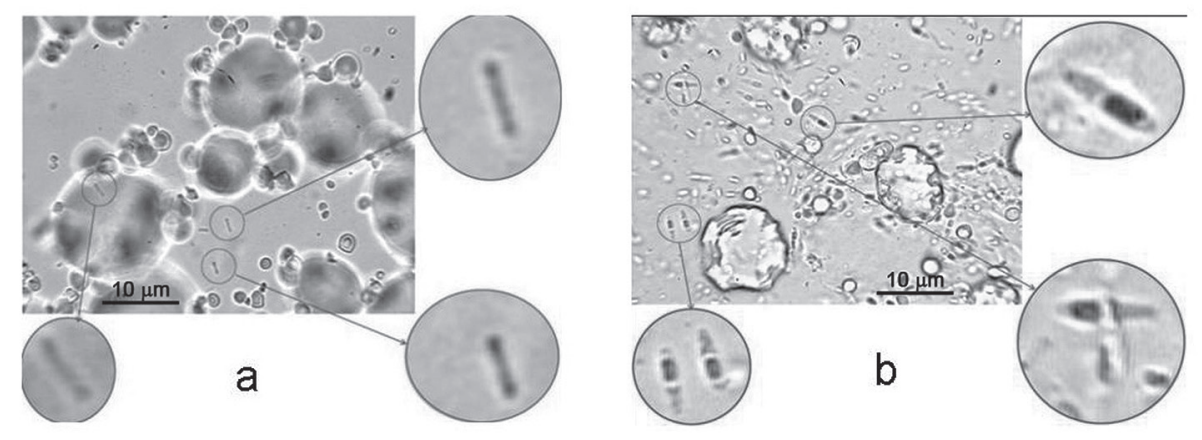

Fig. 2. Xanthomonas translucens bacteria in the endosperm part of spring wheat seeds: $a, 72 \mathrm{~h}$ of incubation; $b, 200 \mathrm{~h}$ of incubation

The grown colonies were round-shaped with the diameter up to 4-6 $\mathrm{mm}$ and had a smooth and sometimes slightly mucous surface. The transparency of colonies made 20-40 units, the color was whitish with a yellowish tint, and the edges were even. Based on these morphological characteristics and some biochemical data (not shown), we concluded these bacteria belonged to the Xanthomonas genus.

The concept of the microbiological identification method is intended to confirm the bacterial infection of sampled plants, to transfer pathogens on artificial medium, and to test their pathogenicity after their isolation from nutrition medium.

\section{PCR identification}

The microbiological identification of bacteria, isolated from plants with typical symptoms (leaf tip necroses), as Xanthomonas sp. and specifically X. translucens was confirmed by the PCR analysis (Fig. 3, Table 1). According to the PCR data, the seed material of both spring and winter wheat was infected with plant pathogenic $X$. translucens, described in a classic phytopathological literature as the causal agent of the black bacteriosis of wheat (Matveeva et al., 2006). 


\section{Table 1}

Comparative identification of Xanthomonas translucens on winter and spring wheat by different methods and the severity of natural infection depending on the presence of Pantoea agglomerans

\begin{tabular}{|c|c|c|c|c|c|}
\hline \multirow{2}{*}{ Wheat cultivar } & \multicolumn{3}{|c|}{ Identification method for Xanthomonas translucens } & \multirow{2}{*}{$\begin{array}{l}\text { Severity of } \\
\text { infection } \\
\text { in wheat }\end{array}$} & \multirow{2}{*}{$\begin{array}{c}\text { Presence } \\
\text { of Pantoea } \\
\text { agglomerans }\end{array}$} \\
\hline & Microbiological & PCR & HR on Plectranthus & & \\
\hline \multicolumn{6}{|l|}{ Winter wheat } \\
\hline Orenburgskaya 105 & + & + & + & +++ & + \\
\hline Povolzhskaya & + & +- & + & +++ & + \\
\hline Pionerskaya & + & + & +- & ++++ & + \\
\hline Kolos Orenburzhya & + & + & + & ++ & + \\
\hline \multicolumn{6}{|l|}{ Spring wheat } \\
\hline Uchitel & + & + & + & +++ & + \\
\hline Varyag & + & $\mathrm{n} / \mathrm{d}^{*}$ & $\mathrm{n} / \mathrm{d}^{*}$ & + & - \\
\hline Orenburgskaya 10 & + & $\mathrm{n} / \mathrm{d}$ & $\mathrm{n} / \mathrm{d}$ & + & - \\
\hline Orenburgskaya 21 & + & $\mathrm{n} / \mathrm{d}$ & $\mathrm{n} / \mathrm{d}$ & + & - \\
\hline
\end{tabular}

* not determined.
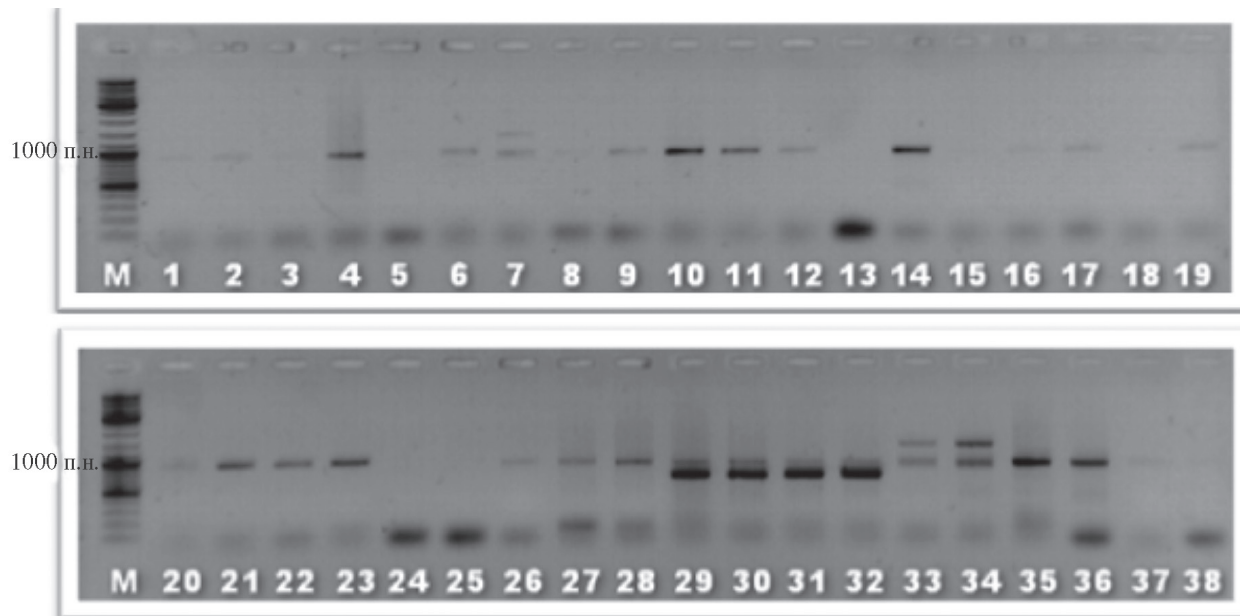

Fig. 3. Electrophoresis of PCR products obtained by the use of species-specific F25/R25 primers for identification of Xanthomonas translucens in wheat samples. M, molecular weight marker (Fermentas). Lanes 1-17 and 20-36: samples collected from winter wheat cvs. Orenburgskaya 105 (lanes 1-2, 5-8, 15-16, 17-20), Povolzhskaya 86 (lanes 3-4); Pionerskaya 32 (lanes 9-10, 21-22) Kolos Orenburzhya (lanes 13-14, 23-24), spring wheat cv. Uchitel (lanes 25-32, 35-36), oats cv. Skakun (lanes 11-12), barley cv. Anna (lines 33-34). Lanes 19 and 37: positive control (DNA of the reference X. translucens pv. undulosa strain 926). Lanes 18 and 38: negative control (no sample DNA) 


\section{Pathogenicity assessment and indirect identification}

The pathogenicity of $X$. translucens isolates was tested by a hypersensitivity reaction (HR) approach using the indicator plant Plectranthus australis. According to the studies of Rogachev (1986) and Samokhvalov et al. (1986), who tested 10 potential indicator plants for their HR towards Xanthomonas campestris, P. australis was characterized by a clear HR towards this pathogen, and its sensitivity significantly exceeded that of other indicator plants; moreover, $P$. australis was much more sensitive to $X$. campestris comparing to some other pathogenic bacteria, such as Pseudomonas spp. (Samokhvalov et al., 1986). The testing of different strains of $X$. campestris showed a good correspondence between their pathogenicity towards the host plant, determined by the classical seed soaking method, and the corresponding HR of P. australis (Rogachev, 1986; Table 2). The sensitivity of the method was $10^{4} \mathrm{CFU} / \mathrm{ml}$. Based on these results, authors proposed $P$. australis as an indicator plant specific to Xanthomonas bacteria.

Next day after artificial inoculation, round brownish necroses were observed on the bottom side of inoculated leaves (Fig. 4). A wide HR variation was observed among the isolates tested; the most intensive reaction was observed in the case of inoculum isolated from winter wheat cv. Pionerskaya 32. Note that isolates collected from spring wheat demonstrated less intensive HR than those from winter wheat (Table 1). A good correspondence between the indirect indicator method of $X$. translucens identification and its molecular identification by PCR was observed.

\section{Effect of co-infection with Pantoea agglomerans}

In addition to $X$. translucens, another bacterium, Pantoea agglomerans, was co-isolated from some of collected samples. This bacterium is considered to be symbiotic and nonpathogenic, and its metabolites are considered to have some immunomodulating properties for humans (Soma et al., 2006). However, in our case, all X. translucens isolates, which caused an intensive HR, were isolated from samples co-infected with P. agglomerans (Table 1). This fact provides a reason to pay more attention to this group of nonpathogenic bacteria. Probably, the harmfulness of $P$. agglomerans is manifested in the enhancement of the negative effect of $X$. translucens. The observed phenomenon requires a more thorough investigation under laboratory conditions.

\section{Improvement of bacterial infection detection in seeds}

In the course of the monitoring of surveyed wheat fields, we noted that the harmfulness and level of development of bacterial diseases, particularly those, which were manifested in the form of yellowish leaf tip necroses, increased under extreme environmental conditions due to increased growth of bacterial mass. Thus, the modeling of stress factors under laboratory conditions would be potentially useful to enhance the disease manifestation during seed assessment and, therefore, improve the primary diagnostics of bacterial diseases. In this study, $\mathrm{pH}$ and temperature were assessed as stress factors to find 
Table 2

Comparison of the pathogenicity of Xanthomonas campestris isolates determined by the hypersensitive reaction of Plectranthus australis and by a cabbage seed soaking method*

\begin{tabular}{ccc}
\hline Isolates tested & Hypersensitive reaction & Infection of cabbage seedlings, \% \\
\hline 1 & - & 0 \\
2 & - & 0 \\
3 & - & 0 \\
4 & - & 0 \\
5 & + & 5 \\
6 & + & 25 \\
7 & + & 100 \\
8 & + & 15 \\
Control (water) & - & 0 \\
\hline
\end{tabular}

* Cyted from Rogachev, 1986.
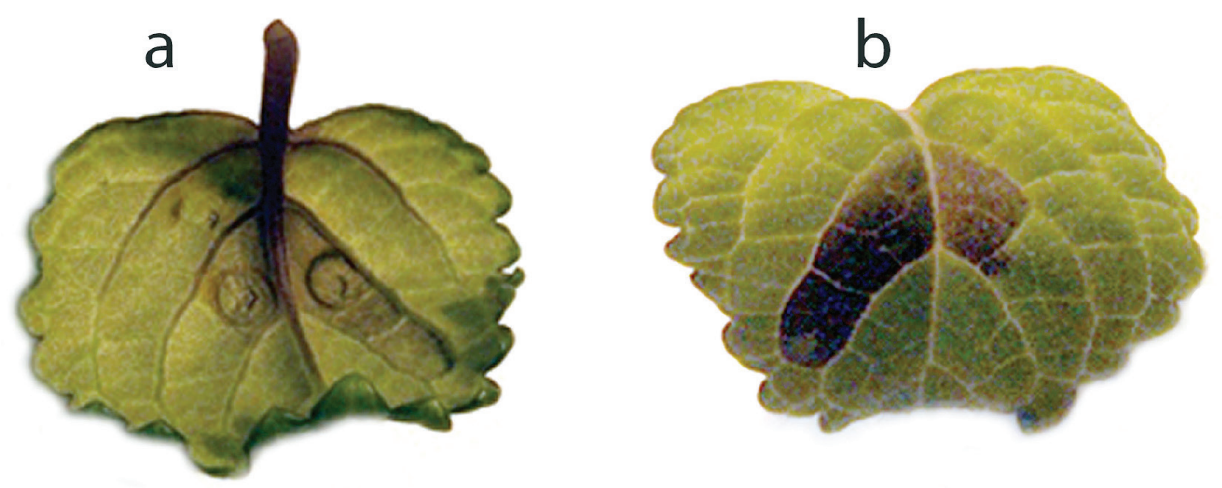

Fig. 4. Hypersensitive reaction of Plectranthus australis leaves inoculated with Xanthomonas translucens isolates: $a$, bottom side of a leaf; $b$, top part of a leaf

the optimum values for the maximum disease manifestation. The results of the study are shown in Table 3.

According to the obtained results, the decrease in a germination temperature down to $5{ }^{\circ} \mathrm{C}$ from the control $\left(25^{\circ} \mathrm{C}\right)$ reduced the germination rate of wheat seeds by $22.4 \%$; in the case of the temperature increase up to $40{ }^{\circ} \mathrm{C}$, the corresponding decrease in the germination rate was $14.5 \%$. Temperature changes influenced the manifestation of total bacterial infection: the level of observed seed infection at $5{ }^{\circ} \mathrm{C}$ almost doubled, reaching $35.3 \%$, whereas increased temperature $\left(40{ }^{\circ} \mathrm{C}\right)$ provided less significant effect, increasing the level of infection by $4.3 \%$ comparing to the control $\left(25^{\circ} \mathrm{C}\right)$.

An increase in the $\mathrm{pH}$ value of incubation solution decreased the germination rate of wheat seeds by $11 \%$ and simultaneously increased the manifestation of bacterial infec- 
Table 3

The effect of temperature and $\mathrm{pH}$ on the germination rate of wheat seeds and level of their bacterial infection*

\begin{tabular}{|c|c|c|c|c|c|}
\hline \multicolumn{3}{|c|}{ Temperature effect, cv. Albidum 188} & \multicolumn{3}{|c|}{ pH effect, cv. Uchitel } \\
\hline Temperature, ${ }^{\circ} \mathrm{C}$ & $\begin{array}{c}\text { Germination rate, } \\
\%\end{array}$ & $\begin{array}{c}\text { Level of infection, } \\
\%\end{array}$ & $\mathrm{pH}$ & $\begin{array}{c}\text { Germination rate, } \\
\%\end{array}$ & $\begin{array}{c}\text { Level of infection, } \\
\%\end{array}$ \\
\hline 5 & $71.0 \pm 2.5$ & $35.3 \pm 6.1$ & Distilled water & $84 \pm 6$ & $52 \pm 6$ \\
\hline 10 & $75.0 \pm 3.4$ & $31.7 \pm 5.0$ & 7.0 & $87 \pm 3$ & $44 \pm 3$ \\
\hline 15 & $82.1 \pm 3.3$ & $24.5 \pm 5.5$ & 7.5 & $86 \pm 5$ & $46 \pm 7$ \\
\hline 20 & $89.5 \pm 4.1$ & $21.1 \pm 2.2$ & 8.0 & $86 \pm 4$ & $54 \pm 5$ \\
\hline 25 & $93.4 \pm 2.5$ & $16.7 \pm 3.4$ & 8.5 & $84 \pm 3$ & $59 \pm 3$ \\
\hline 30 & $82.7 \pm 1.8$ & $20.6 \pm 2.7$ & 9.0 & $73 \pm 4$ & $58 \pm 3$ \\
\hline 35 & $80.9 \pm 2.7$ & $20.0 \pm 3.3$ & 9.5 & $73 \pm 3$ & $57 \pm 4$ \\
\hline 40 & $78.9 \pm 3.1$ & $20.6 \pm 2.7$ & 10.0 & $73 \pm 3$ & $59 \pm 2$ \\
\hline
\end{tabular}

*The data shown represent average values \pm standard errors.

tion by $7 \%$ as compared with the control. The similar results were obtained for the use of $0.1 \mathrm{M} \mathrm{Na}_{2} \mathrm{CO}_{3}$ and mix of $0.1 \mathrm{M} \mathrm{Na}_{2} \mathrm{CO}_{3}$ and $0.1 \mathrm{M} \mathrm{NaHCO}_{3}$ (data not shown).

Thus, the decreased temperature of incubation and increased $\mathrm{pH}$ value are able to stimulate the manifestation of bacterial infection in wheat seeds and, therefore, increase the reliability of a primary diagnostics of a bacterial nature of infection by the paper roll method. These approaches can be recommended for the use as an alternative to the addition of heavy metal salts to the incubation medium commonly used as an artificial stress factor inducing the development of bacterial infection.

\section{Conclusion}

Microbiological identification of pathogenic agents isolated from infected wheat seeds and plants, collected in the Southern Ural region and characterized by an atypical manifestation of bacterial infection (yellow leaf tips), confirmed their belonging to the genus Xanthomonas. The reliability of primary diagnostics of bacterial infection of seeds by paper roll method can be improved by simple decrease in the temperature of incubation or by $\mathrm{pH}$ increase which provoke the manifestation of hidden infection.

The PCR analysis of isolates using species-specific primers provided their identification as $X$. translucens; the reliability of the obtained results was comparable with those obtained by the HR approach. The pathogenicity of the studied isolates varied. Plants, especially winter wheat, from which not only $X$. translucens but also $P$. agglomerans could be isolated, showed more severe disease symptoms than spring wheat, where only $X$. translucens was found. 


\section{Acknowledgements}

Authors thank to their colleagues from the Orenburg State University for their kind assistance in the isolation of collected pathogens. Authors thank also to their colleagues from the Center of Bioengineering of the Russian Academy of Sciences for their assistance in the PCR identification of the studied pathogens and provision of the indicator plant $P$. australis.

\section{Literature}

Birnboim, H. C. and Doly, J. (1979): A rapid alkaline extraction procedure for screening recombinant plasmid DNA. Nucl. Acids Res. 7, 1513-1523.

Egorova, M. S., Mazurin, E. S., Polityko, V. A. and Ignatov, A. N. (2014): Diversity of phytopathogenic bacteria of genus Xanthomonas isolated from Poaceae plants in Russia. Bulletin of Russian Peoples' Friendship University. 4, 47-53.

Glinushkin, A. P. (2013): Phytopathogenic complex of wheat and its control. Doct. Thesises. Moscow, 336 p.

Hayard, A. C. (1960): A method for characterizing Pseudomonas solanacearum. Nature 186, 405-406.

Ignatov, A. N. (2014): Occurrence of emerging bacterial plant pathogens in Russia. Zashchita kartofelya (Potato Protection) 2, 53-57 (in Russian).

Ignatov, A. N., Knyazev, A. N. and Vinogradova, S. V. (2012): Bacterial diseases in Russia: the threat is real. Zashchita rastenii (Plant Protection) 6, 16-17 (in Russian).

International Seed Testing Association (1966): International Rules for Seed Testing. Proc. of the International Seed Testing Association 31, 1-152.

Kharchenko, A. G. (2012): Bacterial diseases are masked as starvation. Zashchita rastenii (Plant Protection) 3, 12-13 (in Russian).

Matveeva, E. V., Polityko, V. A. and Ignatov, A. N. (2006): Black rot of cereals: phenotypic and molecular characteristics of the Russian strains of Xanthomonas translucens. Agro XXI 10-12, 27-30 (in Russian).

Prasada, M. N., Sajwan, K. S. and Naidu, R. (2005): Trace Elements in the Environment: Biogeochemistry, Biotechnology, and Bioremediation. CRC Press, Boca Raton, USA, 744 p.

Punina, N. V., Zotov, V. S., Kuznetsov, B. B. and Ignatov, A. N. (2008): Evaluation of variability of 16S-23S internal transcribed spacer, gyrase B gene and development of PCR diagnostics for plant pathogenic Xanthomonads. Bulletin of Moscow State Regional University ("Natural Sciences" series) 2, pp. 3-17.

Rogachev, Yu. B. (1986): New biotests to determine the pathogenicity of Xanthomonas campestris pv. campestris. In: Selection of Vegetable Crops. Selected papers. All Russian Research Institute of Vegetable Breeding and Seed Production, Moscow, pp. 99-101 (in Russian).

Samokhvalov, A. N., Rogachev, Yu. B. and Afanasyeva, O. G. (1986): On the possibility of the use of a hypersensitive reaction for intraspecific differentiation of pathogens causing black rot of cabbage and angular leaf spot of cucumber. In: Selection of Vegetable Crops. Selected papers. All Russian Research Institute of Vegetable Breeding and Seed Production, Moscow, pp. 89-92 (in Russian).

Schaad, N. W., Jones, J. B. and Chun, W. (2001): A Laboratory Guide for Identification of Plant Pathogenic Bacteria. 3rd ed. Am. Phytopathol. Society, St. Paul, MN, 373 p.

Schaad, N. W., Frederick, R. D., Shaw, J., Schneider, W. L., Hickson, R., Petrillo, M. D. and Luster, D. G. (2003): Advances in molecular-based diagnostics in meeting crop biosecurity and phytosanitary issues. Ann. Rev. Phytopathol. 41, 305-324.

Soma, G.-I., Kohchi, C., Inagawa, H., Nishizawa, T. and Takahashi, Y. (2006): Method for fermentation and cultivation, fermented plant extract, fermented plant extract powder, and composition containing the extract of fermented plant. US Patent 8075928.

Vauterin, L., Hoste, B., Kersters, K. and Swings, J. (1995): Reclassification of Xanthomonas. Int. J. Syst. Bacteriol. 45, 472-489.

Vidaver, A. K. (1989): Gram positive bacteria. In: N. W. Shaad (ed.): Laboratory Guide for Identification of Plant Pathogenic Bacteria. Am. Phytopathol. Society, St. Paul, MN, pp. 12-16. 